\title{
Buried large block revealed by gravity anomalies in the Tonankai and Nankai earthquakes regions, southwestern Japan
}

\author{
Ryo Honda and Yoshiteru Kono \\ Graduate School of Natural Science and Technology, Kanazawa University, Kakuma-machi, Kanazawa 920-1192, Japan
}

(Received November 4, 2004; Revised December 24, 2004; Accepted January 29, 2005)

\begin{abstract}
We confirmed existence of a buried large block beneath seafloor off Cape Shionomisaki, Kii Peninsula, southwestern Japan, by improving marine gravity data. We found that the 1944 Tonankai and 1946 Nankai earthquakes occurred close to this block. The block is characterized by high gravity anomalies of $80 \mathrm{mGal}$ larger than surrounding area with a diameter of about $40 \mathrm{~km}$. Center of the anomaly is located $30 \mathrm{~km}$ off Cape Shionomisaki, southern end of the Kii Peninsula. This high gravity anomaly can be explained by existence of a higher density body with approximate thickness of $8 \mathrm{~km}$ just beneath the seafloor. This block coincides with the reported high velocity zone from recent seismic refraction survey in this area. Judging from seismic velocity, density, and geologic evidences, the block presumably consists of intruded acidic rocks, not seamount.
\end{abstract}

Key words: Gravity anomaly, Cape Shionomisaki, Nankai earthquake, Tonankai earthquake.

\section{Introduction}

The Nankai Trough is one of the most seismically active zones in the Japanese Islands. The trench-type great earthquakes have been recurrently occurring approximately every 100 years. It has long been believed that trench-type great earthquakes in the Nankai Trough generally rupture at each segment (Ando, 1975).

Recently, we recalculated detailed terrain gravity correction not only for land but also for sea, using $50 \mathrm{~m} \mathrm{mesh}$ topography data (Honda and Kono, 2005). Assuming both densities for Bouguer reduction and terrain correction as $2,670 \mathrm{~kg} / \mathrm{m}^{3}$ and using the Kanazawa University gravity database (in preparation; originally Kono and Furuse, 1989, 1990), we produced revised gravity anomaly maps all over the Japanese Islands and its environs. Marine gravity data is mainly provided from the Japan Oceanographic Data Center, Japan Coast Guard (JODC, JCG).

In this paper, we report about a distinct gravity feature observed off Cape Shionomisaki, which is considered to be one of the boundaries of the rupture segments proposed by Ando (1975).

\section{Topography and Gravity Anomalies}

Figure 1(a) shows topographic relief of the studied area. Marine topography is based on the data of the JEGG-500 (500 m mesh bathymetric data) provided from the JODC. The Nankai trough runs southern offshore off Kii Peninsula. Cape Shionomisaki is situated at the southern end of the Kii Peninsula. Shionomisaki Marine Canyon runs from the Kii Strait, between the Peninsula and Shikoku, toward southeast. Two stars around the Kii Peninsula indicate epicenters of the 1944 Tonankai (M7.9) and 1946 Nankai (M8)

Copy right(c) The Society of Geomagnetism and Earth, Planetary and Space Sciences (SGEPSS); The Seismological Society of Japan; The Volcanological Society of Japan; The Geodetic Society of Japan; The Japanese Society for Planetary Sciences; TERRAPUB earthquakes, respectively. Data of epicenters are cited from Kanamori (1972).

Figure 1(b) indicates Bouguer anomalies in the studied area with gravity measurement points (white dots). A thick dashed line indicates a trace of approximate location of the axis of the Nankai trough. Stars are the same as in Fig. 1(a). Bouguer anomalies are higher in the Shikoku basin (about $300 \mathrm{mGal}$ ) and decrease from trench axis toward land. The minimum value in the studied area is minus $40 \mathrm{mGal}$ in inland area.

Though there are not enough gravity measurement points, high gravity anomalies clearly appeared off Cape Shionomisaki. Amplitude of the gravity anomalies is about $80 \mathrm{mGal}$, and an approximate diameter of distribution of the high anomaly is about $40 \mathrm{~km}$. Center of the anomaly is $30 \mathrm{~km}$ south from Cape Shionomisaki. We named this high gravity anomaly as "Off Cape Shionomisaki High Gravity Anomaly" (Honda and Kono, 2005). Here we assumed a Bouguer density as $2,670 \mathrm{~kg} / \mathrm{m}^{3}$. There is no drastic change in distribution pattern of the Bouguer anomalies by changing this assumption, since ocean bottom topography is so flat. Water depth in this region is about 2,000 $\mathrm{m}$ and rather flat except the Shionomisaki Canyon. From the topographic point of view, there are no distinct surface features corresponding to this high anomaly.

Due to dense land gravity measurement points, it is quite clear that the gravity anomalies over the Kii Peninsula become higher southward to Cape Shionomisaki. There is a high gravity anomaly of $150 \mathrm{mGal}$ over Cape Shionomisaki and immediately offshore the Cape (Geological Survey of Japan, 1977). There seems to be a regional gravity rise, which includes the southern part of the Kii Peninsula and the Off Cape Shionomisaki High Gravity Anomaly. However, the detail is not clear due to sparse distribution of marine gravity measurement points. 


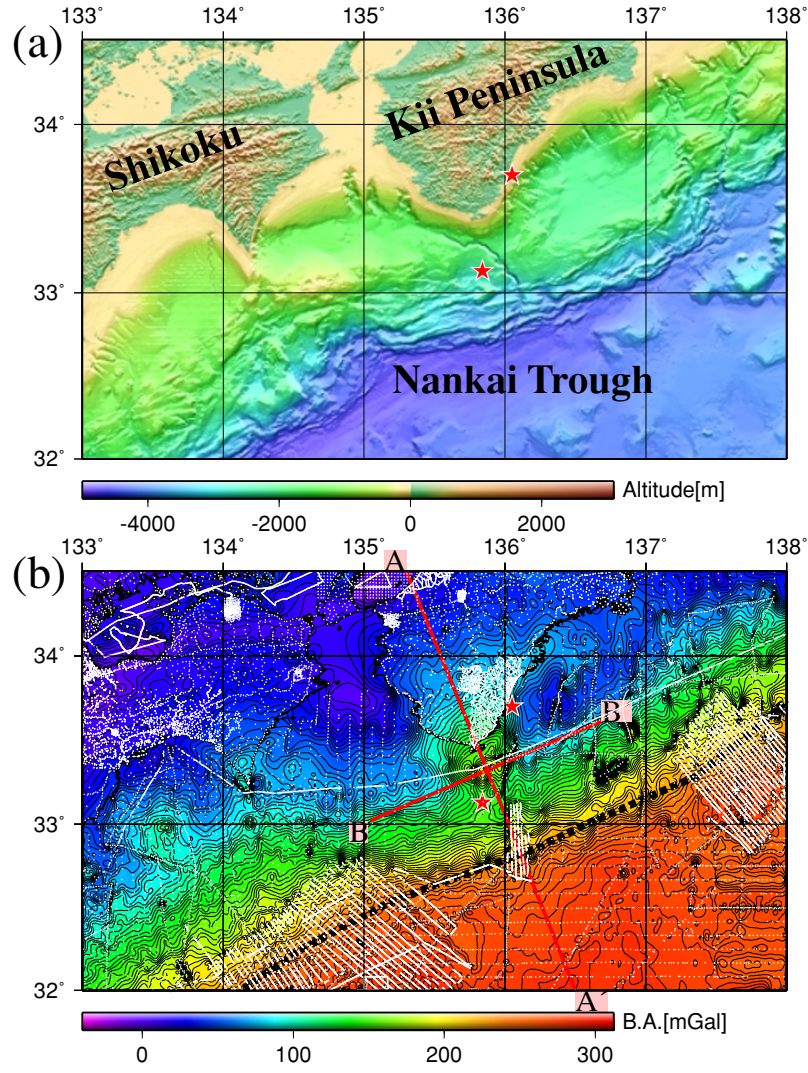

Fig. 1. (a): Topographic relief of the studied area. Marine topography is based JEGG-500. Two stars offshore of the Kii Peninsula indicate epicenters of the 1944 Tonankai (M7.9) and 1946 Nankai (M8) earthquakes, respectively. Data of epicenters are cited from Kanamori (1972). (b): Bouguer anomalies in the studied area with gravity stations (dots). A thick dashed line indicates a trace of approximate location of the axis of the Nankai trough. Stars are the same as in Fig. 1(a). Two red lines, $\mathrm{A}-\mathrm{A}^{\prime}$ and $\mathrm{B}-\mathrm{B}^{\prime}$, are the locations of profiles illustrated in Fig. 2.

\section{Results and Discussions}

Figure 2 shows north-south (A-A' in Fig. 1(b)) and eastwest (B- $\mathrm{B}^{\prime}$ in Fig. 1(b)) profiles of topographies and gravity anomalies across the center of the high gravity anomaly region, respectively. In Fig. 2(a), two observed gravity anomalies are indicated, i.e., gravity anomalies with and without seafloor terrain correction. It is obvious that the gravity anomalies were smoothed by seafloor terrain correction.

A model to explain these features is as follows: (1) a cylindrical block, with a height of $10 \mathrm{~km}$ and a diameter of $40 \mathrm{~km}$, and (2) density contrast of $400 \mathrm{~kg} / \mathrm{m}^{3}$ between the block and surroundings (Turcotte and Schubert, 1982). If the density contrast is $200 \mathrm{~kg} / \mathrm{m}^{3}$, a cylinder of $20 \mathrm{~km}$ height is required to explain the observed gravity anomaly. In Fig. 3, theoretical and observed gravity anomalies are compared in profile B. Variation of marine Bouguer anomalies is scarcely affected by assumed density, because ocean bottom topography is rather flat in studied area. This model is consistent with the recent seismic refraction survey in this region (Line NT03; Kodaira et al., 2004). According to their results, a P-wave velocity region of about $5 \mathrm{~km} / \mathrm{sec}$ (hereafter we call this region as "body") swells up in sedimentary layers by about $10 \mathrm{~km}$ from the lower layer that

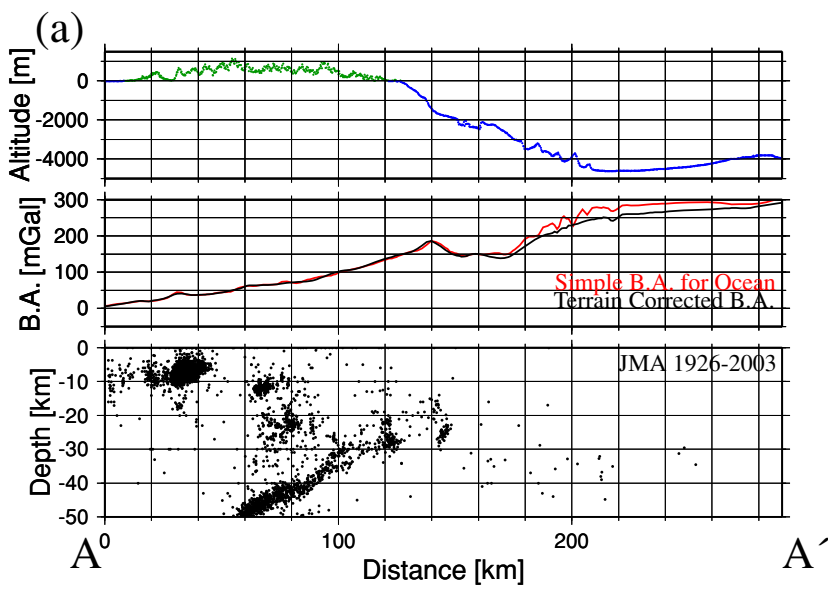

(b)



Fig. 2. (a): North-south profile of topographies (upper), gravity anomalies (middle), and seismicities (lower) across the center of the high gravity anomaly region $\left(\mathrm{A}-\mathrm{A}^{\prime}\right.$ in Fig. 1(b)). (b): East-west profile $\left(\mathrm{B}-\mathrm{B}^{\prime}\right.$ in Fig. 1(b)). Approximate traces of P-wave velocities of $4.5 \mathrm{~km} / \mathrm{s}$ and 6 $\mathrm{km} / \mathrm{s}$ (Kodaira et al., 2004) are indicated with dashed blue lines (lower).

presumably corresponds to oceanic layer. Seismic velocities of surroundings of the body are from 3 to $4 \mathrm{~km} / \mathrm{sec}$. The diameter of the body is about $40 \mathrm{~km}$, and agrees with that of the high gravity anomaly region. In Fig. 2(b), trace of the boundary of the body is compared with gravity anomalies along the observed line. This strongly suggests consistency between seismic results and gravity data.

By converting seismic velocities to density values using empirical relationship such as Nafe and Drake diagram (Ludwig et al., 1970), density of the body and density contrast between the body and surroundings are evaluated to be about 2,600 and $300 \mathrm{~kg} / \mathrm{m}^{3}$, respectively.

Seismic refraction studies and its geological interpretation suggest that the basement of sedimentary layer is the pre-Neogene to early Miocene (Geological Survey of Japan, 1977). Density of rocks of the same period in Japan is usually about 2,300 to $2,400 \mathrm{~kg} / \mathrm{m}^{3}$ (e.g., Kono and Furuse, 1989). If the density contrast between the block and surrounding sedimentary layers is 300 to $400 \mathrm{~kg} / \mathrm{m} 3$, the most probable density of the block is 2,600 to $2,700 \mathrm{~kg} / \mathrm{m}^{3}$, and is at most $2800 \mathrm{~kg} / \mathrm{m}^{3}$.

Judging from physical properties inferred from seismic velocities and density of the blocks, one candidate of rock type of the block is granitic rocks. According to marine 



Fig. 3. Theoretical values (line) calculated using model to explain observed Bouguer anomaly (dots) of the Off-Cape Shionomisaki High Gravity Anomaly (upper). The observed values are interpolated one. The model (lower) is a cylindrical block, with a thickness of $8 \mathrm{~km}$ from the seafloor and a diameter of $40 \mathrm{~km}$. Density contrast between the block and the surroundings was set to $400 \mathrm{~kg} / \mathrm{m}^{3}$.

geological map (Geological Survey of Japan, 1977) there is a small outcrop of acidic rock, which is correlated to the Kumano Plutonic rocks, Middle Miocene, $10 \mathrm{~km}$ off Cape Shionomisaki. The same types of rocks occur at Cape Shionomisaki and also in various parts of the Kii Peninsula. The age of the Kumano plutonic rock is supposed to be preNeogene to early Miocene (Geological Survey of Japan, 1977), and rock densities are reported to be from 2,520 $\mathrm{kg} / \mathrm{m}^{3}$ to $2,660 \mathrm{~kg} / \mathrm{m}^{3}$ (Tanaka and Kanaya, 1987). We also remark that a slightly high magnetic anomaly of about 50 nT appears in the same region of the Off Cape Shionomisaki High Gravity Anomaly (Geological Survey of Japan, 1992).

Taking into account of available information, such as seismic velocity, multi-channel structure, density, and geology, the block seems to consist of acidic rocks, which have intruded into shallow crust. This implies that the block is presumably not a seamount, such as bodies already discovered at the region off Cape Muroto (Park et al., 1999; Kodaira et al., 2000).

Generally, seismicity is not active around Cape Shionomisaki. Particularly within the block region, the seismicity is very low. It seems only few small earthquakes are occurring at the bottom of the block. This suggests that the block is homogeneous.

It is interesting that the epicenters of two great earthquakes (the 1944 Tonankai and the 1946 Nankai earthquake) are situated at the flank of the high gravity anomaly region (Off Cape Shionomisaki High Gravity Anomaly). Slip distributions of these earthquakes were simulated from tsunami analyses (Tanioka and Satake, 2001; Baba et al., 2002). Kikuchi et al. (2003) also discusses about the slip distribution of Tonankai Earthquake by analyzing low-gain seismograms. The estimated slip under the present block is very small in the 1944 Tonankai earthquake, while it is

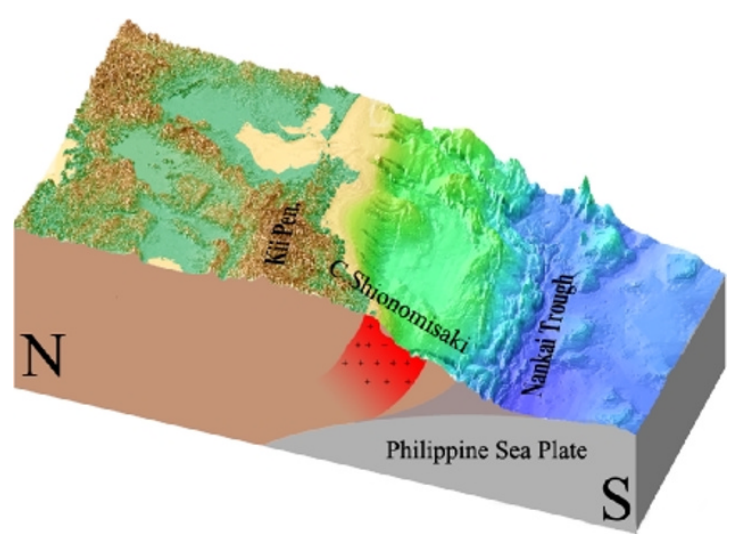

Fig. 4. Schematic model of crustal structure around Cape Shionomisaki.

large in the 1946 Nankai earthquake. There are various discussions on the role of obstacles such as buried seamounts with initiation of great earthquakes (e.g., Ruff, 1989; Cools, 1992; McCaffrey, 1993; Scholz and Small, 1997). The present block might be a key to understand the rupture patterns of the recurrent great earthquakes along the Nankai Trough.

\section{Summary}

A large high-density block is discovered offshore Cape Shionomisaki. Amplitude and diameter of the gravity anomalies are $80 \mathrm{mGal}$ and $40 \mathrm{~km}$, respectively. The block, which causes this anomaly, is estimated to be $10 \mathrm{~km}$ deep and $40 \mathrm{~km}$ wide, with a density contrast of around 400 $\mathrm{kg} / \mathrm{cm}^{3}$. This model is consistent with one of the seismic refraction experiments. Judging from both physical properties and geological evidences, this block presumably consists of intruded acidic rocks but not either basic or ultrabasic rocks. By carrying out more detailed and various geophysical observations in this area, more accurate distribution of the block and also precise plate boundary conditions may be revealed, which would resolve the role of the newly found block to the occurrence of great earthquakes around the Nankai Trough.

Acknowledgments. We are thankful for discussion to Dr. Baba, the Institute for Frontier Research on Earth Evolution, Japan Agency for Marine-Earth Science and Technology (IFREE, JAMSTEC). We would like to thank the Japan Oceanographic Data Center, Japan Coast Guard (JODC, JCG) for providing marine gravity and topographic data. We are grateful to two anonymous referees for constructive comments, which led us to improve the manuscript. All the figures were drawn using the Generic Mapping Tools (Wessel and Smith, 1997).

\section{References}

Ando, M., Source mechanisms and tectonic significance of historical earthquakes along the Nankai Trough, Japan, Tectonophysics, 27, 119-140, 1975.

Baba, T., Y. Tanioka, P. R. Cummins, and K. Uhira, The slip distribution of the 1946 Nankai earthquake estimated from tsunami inversion using a new plate model, Phys. Earth Planet. Inter., 132, 59-73, 2002.

Cools, M., Thrust-type subduction-zone earthquakes and seamount asperities: A physical model for seismic rupture, Geology, 20, 601-604, 1992. Geological Survey of Japan, Marine Geology Map Series, 5, Geological Map of the South of Kii Strait, 1:200,000 (4 Sheets), 1977.

Geological Survey of Japan, Magnetic map of Japan, 1:2,000,000 (sheet), 
1992.

Honda, R. and Y. Kono, Synthesize land and sea 50M digital elevation model and terrain gravity correction in and around the Japanese Islands, J. Geod. Soc. Japan, 2005 (in press).

Kanamori, H., Tectonic Implications of the 1944 Tonankai and the 1946 Nankai Earthquakes, Phys. Earth Planet. Int., 5, 129-139, 1972.

Kikuchi, M., M. Nakamura, and K. Yoshikawa, Source rupture processes of the 1944 Tonankai earthquake and the 1945 Mikawa earthquake derived from low-gain seismograms, Earth Planets Space, 55, 159-172, 2003.

Kodaira, S., N. Takahashi, A. Nakanishi, S. Miura, and Y. Kaneda, Subducted seamount imaged in the rupture zone of the 1946 Nankai Earthquake, Science, 289, 104-106, 2000.

Kodaira, S., J.-O. Park, Y. Kaneda, and T. Iwasaki, What deep seismic imaging tells us about subduction process in the Nankai active continental mergin, 62-63, abstracts for 11th International Symposium on Deep Structure of the Continents and their Margins, 2004.

Kono Y. and N. Furuse, 1:1 Million Scale Gravity Anomaly Map in and around the Japanese Islands, Univ. Tokyo Press, 88 pp., 1989.

Kono, Y. and N. Furuse, Digital Compilation of Gravity Data over the Japanese Islands, in Gravity, Gradiometry, and Gravimetry, Int. Assoc. Geodesy. Symposia 103, edited by R. Rummel and R. G. Hipkin, Springer-Verlag, 133-140, 1990.

Ludwig, W., J. E. Nafe, and C. L. Drake, Seismic Refraction, in The Sea, Vol. 4, Part 1, edited by A. E. Maxwell, Wiley-Interscience, 791 pp.,
1970

McCaffrey, R., On the role of the upper plate in great subduction zone earthquakes, J. Geophys. Res., 98, 11953-11966, 1993.

Park, J.-O., T. Tsuru, Y. Kaneda, Y. Kono, S. Kodaira, N. Takahashi, and H. Kinoshita, A subduction seamount beneath the Nankai Accretionary prism off Shikoku, southwestern Japan, Geophys. Res. Lett., 26, 931934, 1999.

Ruff, L. J., Do trench sediments affect great earthquake occurrence in subduction zones?, Pure Appl. Geophys., 129, 263-282, 1989.

Scholz, C. H. and C. Small, The effect of seamount subduction on seismic coupling, Geology, 25, 478-490, 1997.

Tanaka, S. and H. Kanaya, Some physical properties of Kumano acidic rocks-density, magnetic susceptibility and acoustic velocity-, Bull. Geol. Surv. Japan, 38, 423-426, 1987.

Tanioka, Y. and K. Satake, Detailed coseismic slip distribution of the 1944 Tonankai earthquake estimated from tsunami waveforms, Geophys. Res. Lett., 28, 1075-1078, 2001.

Turcotte, D. L. and G. Schubert, Geodynamics, Cambridge University Press, 1982.

Wessel, P. and W. H. F. Smith, New, improved version of the Generic Mapping Tools released, EOS Trans. AGU, 79, 579, 1997.

R. Honda (e-mail: ryo@earth.s.kanazawa-u.ac.jp) and Y. Kono 